\title{
Construction of Innovative and Entrepreneurial Faculty in Publishing Majors in Applied Undergraduate Colleges
}

\author{
Liya Yao \\ Jilin Engineering Normal University, 130052 \\ 415356818@qq.com
}

Keywords: Applied undergraduate colleges; Publishing major; Faculty construction

\begin{abstract}
As the structure of higher education in China continues to adjust, the applied undergraduate has become an important part of higher education, and the publishing profession is a base for training professional talents such as professional technical editors and publishing business management. Team building requirements are higher. The existing college teachers' construction theory is partial, and there are few teachers with practical experience, which brings many difficulties to the teaching work. In addition, publishing is a fast-growing industry, and the quality requirements for talents are getting higher and higher. Therefore, the constant innovation of the construction of the teaching staff is to train more qualified application talents.
\end{abstract}

\section{Introduction}

Different from the undergraduate colleges that take scientific research as the purpose of running a school, the applied undergraduate, as the name implies, is an institution that cultivates practical and applied talents as the goal of running a school[1]. This is an important reform made by higher education to adapt to the development of China's market economy under the new situation in the new era. Due to the short development time of applied undergraduate courses and the preference for science and engineering majors in professional setting, there is a double demand for teachers' teaching level and professional skills, that is, the demand for teachers holding "dual qualification certificates" is greater. This is an important feature of the construction of the teaching staff of applied undergraduate colleges[2].

\section{The Status Quo of the Teaching Staff of Applied Undergraduate Colleges}

Applied undergraduate colleges are China's reforms to higher education in order to adapt to the development of market economy. The traditional higher vocational education and undergraduate education are organically integrated, and the essence of the two educational models is combined to explore a new educational model. Applied undergraduate colleges are based on provincial and national higher vocational colleges, and jointly with large enterprises to carry out pilot teaching, with the aim of cultivating new applied undergraduate talents [3]. This is a brand-new educational model. The theoretical knowledge of the trained talents is more solid than the traditional higher vocational students, and the practical ability is not inferior. Especially in the cultivation of talent innovation ability, due to the solid theoretical knowledge as a guarantee, the combination of practical ability and thinking ability has greatly stimulated the talent's innovative ability.

It can be said that practical ability is still the main goal of talent training in applied undergraduate colleges. It inherits the fine tradition of higher vocational education and reflects and reforms contemporary higher education. In addition to stimulating students' innovative ability and practical skills, practical teaching also helps to improve students' professional quality and employment competitiveness, making application-oriented talents more popular with employers [4]. Although the construction of the teaching staff of applied undergraduate colleges has achieved initial results, there are still many shortcomings in terms of actual teaching effects:

First, the number of teachers with dual qualifications is still small and the reserve strength is insufficient. Judging from the prevailing problems in current applied undergraduate colleges, the dual qualifications are still the main problem that plagues teachers and schools. As applied 
undergraduate colleges are emerging transitional institutions, the teachings are insufficient and the construction of the teaching staff has not yet reached the pace of transformation. At present, applied undergraduate colleges are generally transformed from two ways [5]. One is the upgrading of traditional higher vocational colleges, and the other is the transformation of traditional scientific research undergraduate colleges. One is based on practical ability, and the other is strong scientific research ability, but all need to re-adapt to new roles. Applicative undergraduate students trained in applied undergraduate colleges must have sufficient theoretical knowledge and solid practical skills, and these two points are precisely the requirements of teachers. However, due to the fact that the transformation and restructuring of the current applied undergraduate colleges have not been completely completed, even some colleges are still adapting to the role, which has led to the lack of teachers with dual qualifications in many institutions, and the lack of training for existing teachers. Adequate protection and related measures have led to frequent occurrences of insufficient backup forces.

Second, the professional experience of dual-qualified teachers is insufficient. For some teachers with dual teacher qualifications, their professional experience and practical ability have not met the requirements of teaching and educating people. Professional experience is actually a multi-dimensional accumulation of workplace experience and professional skills, and is a comprehensive manifestation of personal values [6]. Applied colleges are more biased towards science and engineering, and professional experience means professional experience. Therefore, the professional experience of teachers is particularly important. It will be a reference for students to plan their careers, and a teacher's professional experience will directly affect whether he has the qualification to become a student professional tutor. At present, many application-oriented undergraduate college teachers have dual professional qualifications, but they lack sufficient professional experience and give people a sense of paperwork in practice teaching.

Third, the construction of the teaching staff did not form a real system. Many applied undergraduate colleges claim to have built a faculty and even formed a team building system. But they only stayed in the initial stage of staffing, and even did not complete the training. Teachers enter colleges and are usually free to develop themselves. How to improve the practical ability of theoretical teachers and how to strengthen the theoretical knowledge of practical teachers, there are few achievements in these areas, lack of corresponding policy guarantees. This leads to the teacher's training system basically copying the scientific research undergraduate colleges, or directly adopting the method of introducing enterprise management talents to teach in higher vocational colleges, but lacking the teacher training system that combines the characteristics of running the school and the teaching needs.

In short, for the application-oriented undergraduate colleges, the emerging teaching institutions, they lack the construction of teachers who are in line with their own school characteristics, and most of them have not yet recognized their identity roles. They either follow the construction model of higher-level teachers, or copy the teacher-training mechanism of scientific undergraduate colleges, and do not form a system of teacher team construction that truly satisfies their own teaching characteristics.

\section{The Demand for the Construction of the Teaching Staff in the Publishing Profession}

The publishing profession covers a wide range of professional fields, including news media, advertising layout, media editing, publishing and printing, business management, etc [7]. It is an institution that specializes in training publishing-type applied technical talents. The publishing profession has a wide range of talents, including editors engaged in text work, professional designers engaged in typographic design, and management talents and propaganda planners engaged in cost accounting and publishing. The wide range of employment of publishing professionals means that teachers' personal qualities are higher. The "personal quality" mentioned here includes both professional literacy and professional experience, and is an evaluation of the comprehensive ability of teachers [8]. The publishing profession has higher requirements for the construction of the teaching staff. 
First, teachers are required to have dual teacher qualifications. As an applied college, this is a basic requirement for teachers. However, in many applied colleges, teachers only have unilateral teaching skills, either theoretical or practical, and there are very few teachers with these two abilities. Some of the teachers only have a certain level of writing skills, and they have served as editors and other courses. However, these courses need to constantly enumerate a large number of examples in order to achieve the purpose of inspiring students. It can be seen that the teacher's dual qualification certificate has a warning effect on his own training.

Second, the requirements for teachers' professional experience are higher. The publishing profession is a profession that requires high practical ability and theoretical knowledge. Teachers should not only guide students to understand theoretical knowledge, but also teach students certain vocational experience so that students can integrate into social competition as soon as possible. Taking text work as an example, from the perspective of news reports or publicity planning work, professional experience is often more important than writing skills. How to edit words in order to be in place requires a good understanding of the editing objects, and these need to rely on professional experience.

Third, the teachers are required to constantly replenish blood. The publishing industry is a fast-changing industry that fluctuates as the market economy changes. In order to cultivate the application-oriented talents that keep pace with the times, on the one hand, teachers need to maintain a curiosity so that teaching activities can keep up with the pace of market economy development; on the other hand, teachers need to constantly add fresh blood. This gives students the latest social information so that students can adjust their career plans in a timely manner.

The publishing major is a major that requires a high level of teachers, especially for the construction of the teaching staff. It requires both generalists and professionals. In other words, teachers in publishing majors need to have rich professional experience and professionalism, otherwise it is difficult to be competent.

\section{The Innovative Strategy of the Construction of the Teaching Staff}

Applied undergraduate and research-based undergraduate courses are all part of higher education, but the two have different educational purposes, and the direction of cultivating talents is different, and the requirements for the construction of faculty are not the same [9]. Especially for publishing a profession that requires a high level of professional experience for teachers, the construction of faculty requires constant innovation to meet the ever-changing market economy.

First, from the introduction to the output, the dual qualification certificate promotes the teacher output plan. In the past, colleges and universities were more likely to hire incumbents of cooperative enterprises as visiting professors or guest base lecturers in practice bases. However, these teaching staff lack real teacher qualification certification, and lack professional teaching skills and teaching experience. They only make a great contribution to the proportion of dual qualifications teachers, and give students more inspiration in the teaching of practical experience. Application-oriented colleges should adopt more of the output plan from the teachers who have the dual qualifications to the enterprise, and exchange the status of employees or part-time employees. They can increase the practical work experience of the teachers. This kind of practical ability to exercise the environment is more conducive to the growth of teachers and the accumulation of experience.

Second, professional experience has become an important basis for reviewing teacher qualifications. We adopt a strategy of mixing schools and enterprises. The teachers are both teachers in the school and formal employees in the company [10]. Instead of adopting the previous corporate job-and-hold training model, we will replace it with a form of communication. On the one hand, teachers integrate into the company to feel the different working environment with the school, and truly touch the forefront of the profession, which helps to accumulate practical work experience; on the other hand, under the enterprise management, teachers also have to undergo performance evaluation. The problem is to help strengthen the sense of responsibility and attention of teachers in corporate communication, improve the effectiveness of communication, and use professional 
experience as an important basis for teacher qualification assessment.

Third, introducing or training teachers from a team perspective. From the perspective of self-team construction, we should introduce or establish a teacher training program, pay attention to the proportion of teachers with dual qualifications, and pay more attention to the proportion of teachers with professional experience, and carry out echelon-style construction. The proportion of teachers in different roles should be balanced. If there is insufficient staff, the introduction and export of the personnel training plan will be realized through various channels such as school-enterprise cooperation, so as to maintain the fresh blood injection of the teacher's team and maintain the vitality of the team.

The professional fields involved in publishing majors are relatively broad, and there are many talent training directions. There are both written work directions, media work directions, and design proofreading. The training of professional and technical talents poses severe challenges for teachers. Not only do teachers need to have dual qualifications, but they also need to have a very rich professional experience in order to develop qualified application-oriented talents that meet the needs of market economy development. Therefore, for the construction of professional teachers in the publishing profession, the complete construction strategy of echelon construction, team building, school-enterprise exchange, and the construction of innovative teams that keep pace with the times will undoubtedly provide guarantee for the cultivation of publishing-type applied talents.

\section{References}

[1] Bin Zeng: Cultivation of Technical Liberal Arts Talents in Application-Oriented Universities[J], Literature Education(last third of a month), 2016(10):144-145.

[2] Feng Sun: Research and Discussion on "Double Qualification" Teacher Training in Application-Oriented Universities[J], English on Campus(FQ), 2017(7):26.

[3] Jialiang Zhu: New Exploration of Project Teaching Mode Based on Application-Oriented Undergraduate Education[J], Art Science and Technology, 2017, 30(8):69.

[4] Xiujun Cheng: A Multiple Angle Discussion on the School Enterprise Cooperation of Applied Undergraduate[J], Social Sciences: Citation Edition, 42.

[5] Dongming Yang: Barrier Breakthrough and Collaborative Innovation: The Path of Transformation and Upgrading of Applied Higher Education[J], Vocational and Technical Education, 2013(6):44-47.

[6] Xiao Xiao: Try to Take a Step More than the Others[J], Labor Security World, 2016(10):49.

[7] Hua Tan: Reconstruction of Basic Elements of Editing and Publishing Talents Training in the Post Printing Era[J], Journal of Hubei University for Nationalities(Philosophy and Social Science), 2016, 34(4):151-155.

[8] Dan Yang: Reflections on How to Improve the Comprehensive Quality of Vocational Teachers in the New Situation[J], The Modern Occupation Education, 2016(6):119.

[9] Liya Wang: Factors Affecting Sustainable Development of Applied Undergraduate Colleges in China[J], Henan Education(Vocational Education Edition), 2016(z1):95-97.

[10] Xinyi Tang and Yinli Xu: Combination of School Enterprise Mix Team to Explore a New Mode of Double Qualified Teacher Team Construction[J], China Higher Education, 2013(9):48-49. 